\title{
DESIGN OF WATER LEVEL CONTROL SYSTEMS USING PID AND ANFIS BASED ON FIREFLY ALGORITHM
}

\author{
Machrus Ali, A.N. Afandi, Asnun Parwanti, Ruslan Hidayat, Cholil Hasyim
}

\begin{abstract}
At present, a controlling system of the fluid flow measurement is needed in industrial processes. Determination of the water quantity is also used to reduce the volume of water usage in the holding tank varies. The effort to overcome this problem has made using a system for regulating performances while a water flow based on the tank volume controlled using a PID system. This system uses a flow sensor to detect the water speed, an electric ball valve as an actuator. In principles, this tool is used to stabilize the output water speed per minute at a predetermined set point. This study is focused in five designed method comparison in associated with a water level without control, standard PID method, PID-Auto tuning method Matlab, PID-FA method, and ANFIS-PIDFA method. The results of the PID-FA training data are used as an input from ANFIS. From the simulation, it is also found that five control models have different performances while the ANFIS-PID-FA model is performed in the best control model. The ANFIS-PID-FA model has also the smallest overshot and undershot on the water level and output flow of $0.0021 \mathrm{pu}, 0.0093 \mathrm{pu}, 0.0072$ pu, and $0.0096 \mathrm{pu}$.
\end{abstract}

Kata Kunci- ANFIS, Firefly Algorithm, PID, Water Level.

\section{INTRODUCTION}

厂 $\mathrm{n}$ general, a physical mechanism of the water level system (WLS) is analyzed while the estimated linear model is also constructed to represent the dynamic property of the WLS around the equilibrium point [1][4]. In addition, the identification method recognizes a dynamic character of the WLS using measured input and output data. Technically, the water tank level instrument is developed using a nonlinear time process control system, which can be modeled globally or

Machrus Ali are with the Electrical Engineering Departement of Universitas Darul Ulum, Jombang, Indonesia (email : machrus7@gmail.com)

A.N. Afandi are with the Electrical Engineering Departement of Universitas Negeri Malang, Malang, Indonesia (email : an.afandi@ieee.org)

Asnun Parwanti are with the Electrical Engineering Departement of Universitas Darul Ulum, Jombang, Indonesia (email : asnunparwanti@gmail.com)

Ruslan Hidayat are with the Electrical Engineering Departement of Universitas Darul Ulum, Jombang, Indonesia (email : ruslanh.1964@gmail.com)

Cholil Hasyim are with the Electrical Engineering Departement of Universitas Darul Ulum, Jombang, Indonesia (email : cholilhasyim57@gmail.com) partially as a water system. Moreover, different models lead to different control strategies which are very important for the overall control system design [5].

Water level control systems are used to control water circulation and the level of water. These processes may include, water dams, petrochemical process plants, water treatment plants, pharmaceuticals, and food processing plants, overhead tanks and others [2],[6],[7]. A device that performs a controlling action is determined by a valve attached to control and maintain the desired set point level [3].

Currently, Artificial Intelligence (AI) is often used to develop various sciences including the Imperialist Competitive Algorithm (ICA) [8][9], Firefly Algorithm (FA) [10], Ant Colony Optimization (ACO)[11], and Particle Swarm Optimization (PSO), Artificial Salmon Tracking Algorithm (ASTA)[12], and ANFIS[13]. In addition, many applied cases have used these algorithms, such as a wind turbine blade control [14], as a DC motor speed control [15], as wind-diesel control [16], a vehicle steer control[8][17], reconfiguration of the distribution network[18][19]. In this work, the ANFIS and proportional integral derivative (PID) controller which is tuned with FA artificial intelligence to control water discharge at the water level in the tank is discussed clearly. The combining ANFIS, PID, and FA methods will also be compared in an effort to control the water flow in the tank.

\section{RESEARCH METHOD}

\section{A. Design of Water Tank System}

The water tank system consists of two block subsystems, namely a valve system and a water tank. Both systems have own functions as joined interaction during an existing the fluid flow as running as on the processes to complete all interactions of the sequencing parts. Technically, the input system is conditioned by the constant value of water discharge, signal generator, and tank maximum inflow. The water flow is supplied using a pump from the storage tank and the water flow is controlled using an actuator as given in Figure 1 


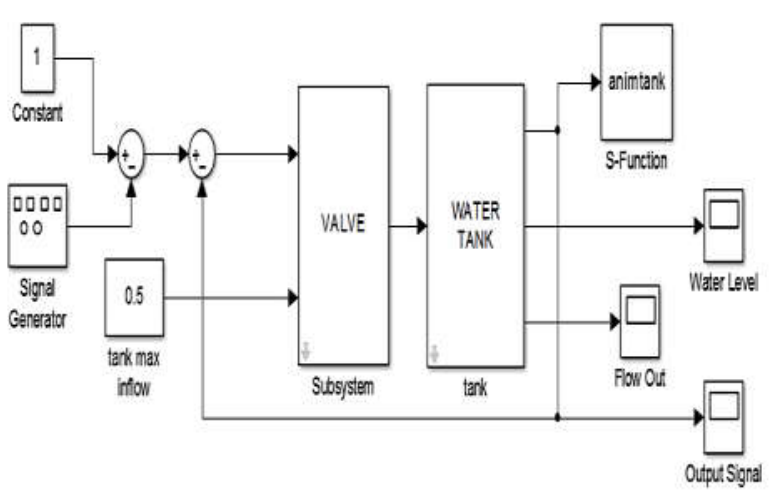

Figure. 1. Simulink Block diagram uncontrolled

As detailed in Figure 1 for the designed water block system, this figure informs that the Simulink block diagram is developed based on the uncontrolled joined subsystems which are interacted in main sections as presented in valve and tank units. In particular, other one is concerned in the controlled system for this interaction as given in Figure 2 using the PID system and Figure 3 for the ANFIS system.

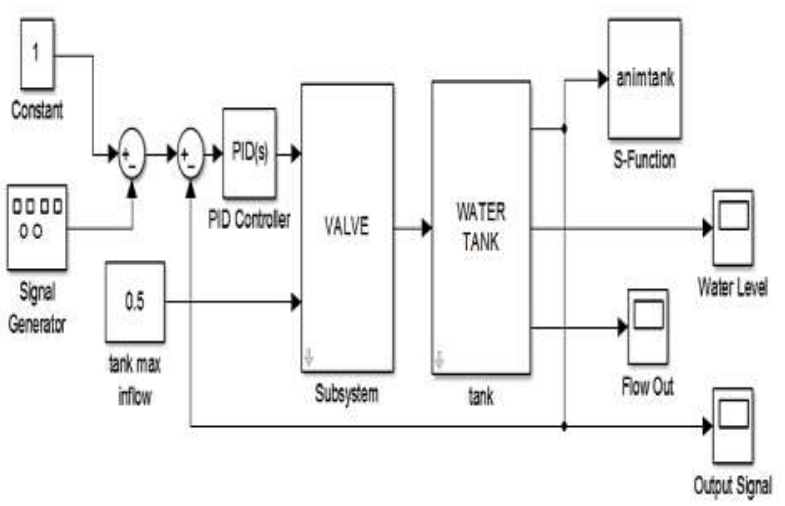

Figure. 2. Simulink Block diagram PID Controller

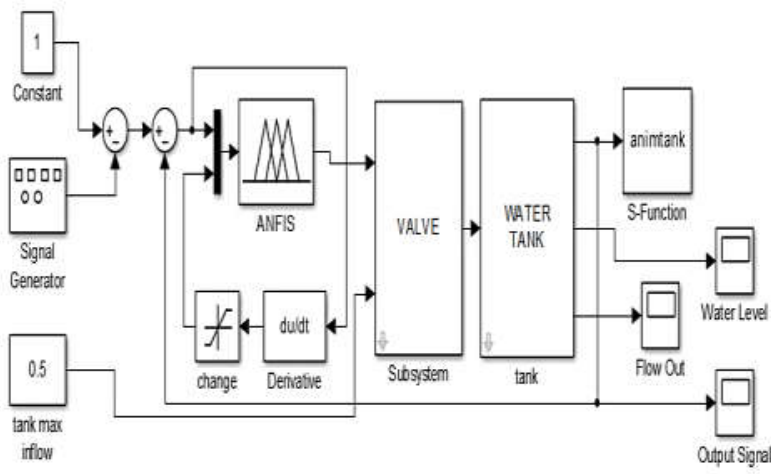

Figure. 3. Simulink ANFIS Block diagram

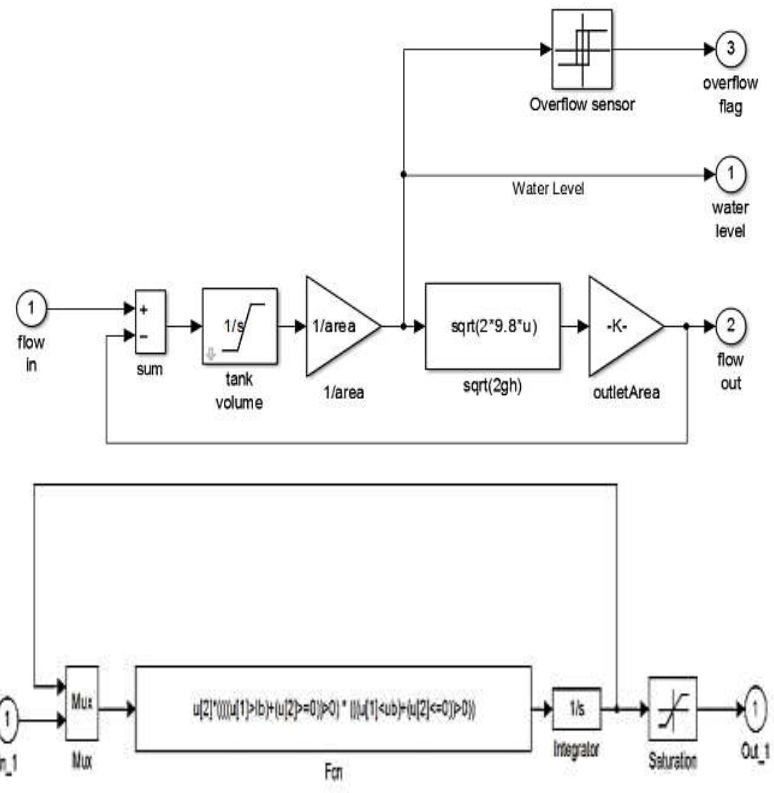

Figure. 4. Water tank subsystem

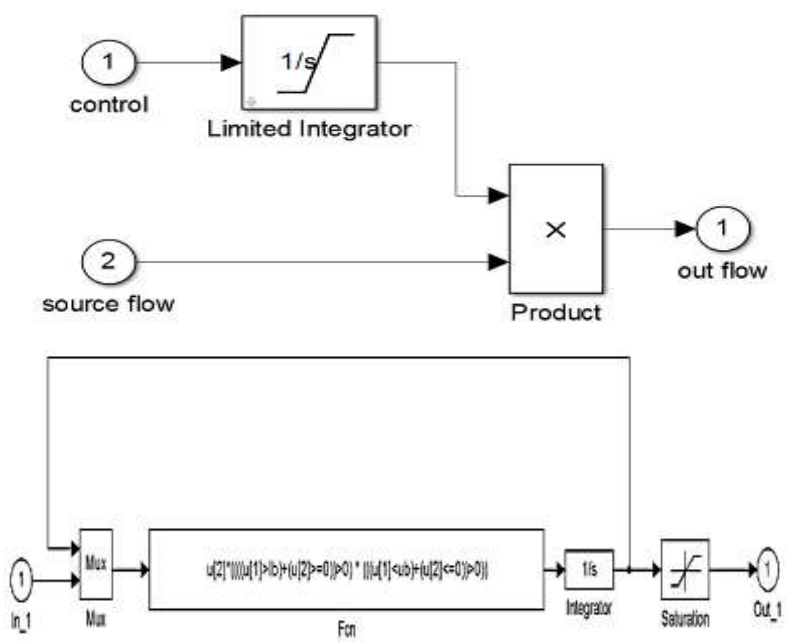

Figure. 5. Valve subsystem

Regarding the water tank system, Figure 4 shows the Simulink block diagram for water tank subsystem and Figure 5 shows the valve subsystem. These systems are subjected to control inlet and outlet of the water during flowing in the tunnel or pipe system. the models are developed based on its criterias to reach and perform its characteristc during the water running.

The indicator light set at the water level can be seen in figure 6. 


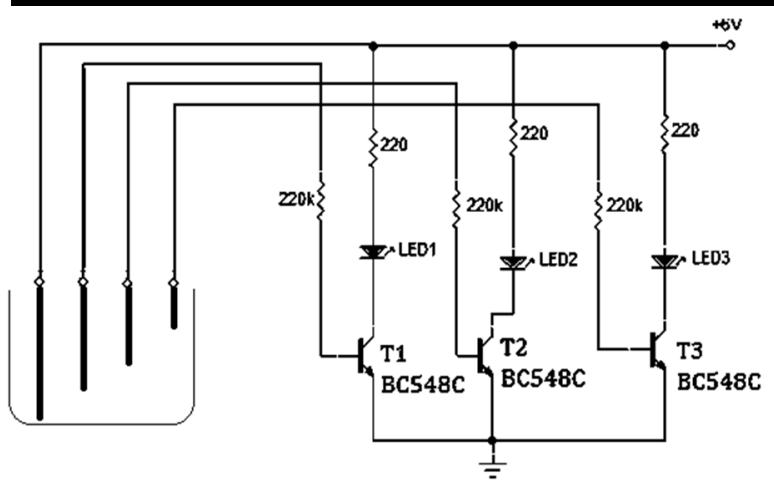

Figure. 6. Simulink Block diagram uncontrolled

\section{B. PID Controller}

Proportional - Integral - Derivative controller (PID) controller is a feedback controller that is mostly used in industrial equipment. A PID controller distinguishes the error between the desired set-point and measurable process variables. PID control has been widely used for equipment control design in the industry, even modified with artificial intelligence[15]. The structure of the PID controller can be seen in Figure 7.

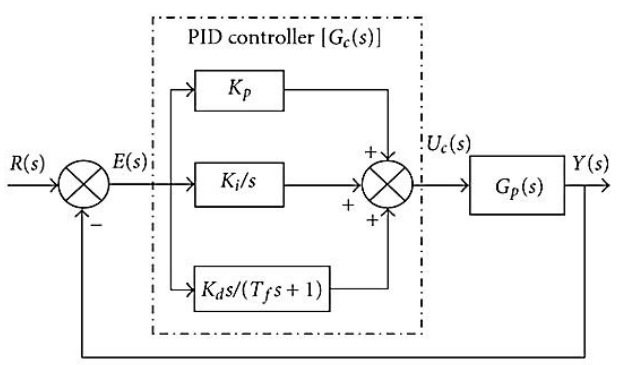

Figure. 7. Structure of PID controller

\section{Firefly Algorithm (FA)}

The desire of a firefly is to attract the attention of other fireflies. Xin-She who formulated this firefly algorithm as follows; All fireflies are unisexual, and will be attracted to other fireflies. Attraction is proportional to its brightness. Fireflies, the less bright ones will be attracted to and approach the firmer fireflies. Brightness intensity decreases in proportion to the distance between fireflies. If there are no fireflies that are brighter, fireflies will move randomly. Brightness must be associated with the objective function. To test the system stability, the objective function is used Integral Time Absolute Error (ITAE)[25].

$$
\text { ITAE }=\int_{0}^{t} t|\Delta \omega(t)| d t
$$

The firefly algorithm can be expressed in pseudocode, with the steps in Figure 7:

The pseudo code of FA can be seen in Figure 7.

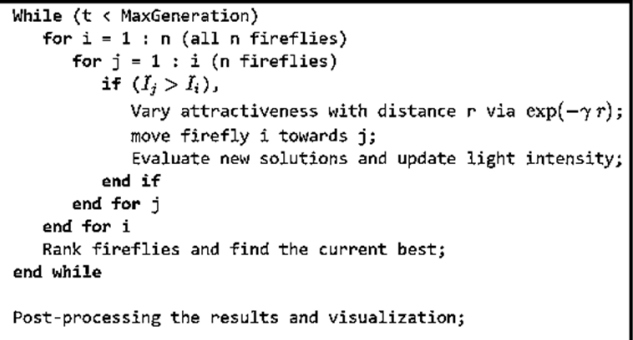

Figure. 8. The pseudo code of the firefly algorithm (FA)

The PID parameters set by FA are Kd, Kp, Ki. The data of the standard FA parameters used are shown in Table 1.

Table 1. FA Parameters

\begin{tabular}{cc}
\hline Parameters & Value \\
\hline Alpha & 0,25 \\
\hline Beta & 0,2 \\
\hline Gamma & 1 \\
\hline Dimensi & 3 \\
\hline Number of fireflies & 50 \\
\hline Maximum Iteration & 50 \\
\hline Kp & $0-50$ \\
\hline Ki & $0-10$ \\
\hline Kd & $0-10$ \\
\hline
\end{tabular}

\section{Adaptive Neuro-Fuzzy Inference System}

The Adaptive-Neuro-Fuzzy-Inference-System (ANFIS) is a kind of artificial neural network based on an inference system from fuzzy Takagi-Sugeno. The ANFIS structure can be seen in Figure 8.

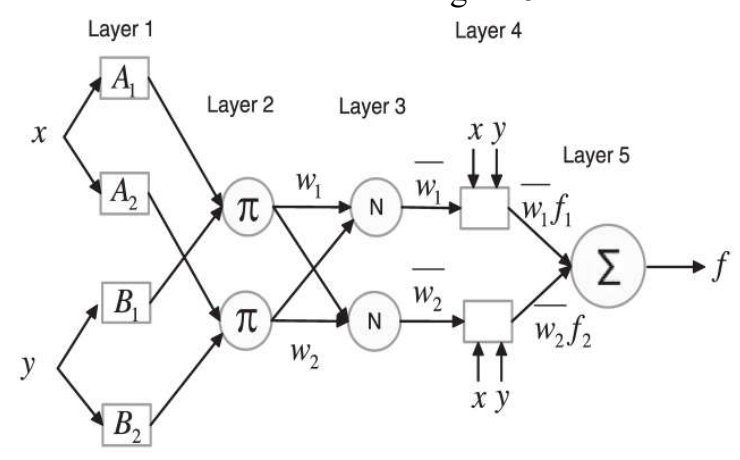

Figure. 9. ANFIS Structure

\section{RESULTS AND ANALYSIS}

As many reported works regarding the ANFIS, PID, and FA applications, these works are also dveloped using a designed model for the problem. In these studies, the Design of Water Level Control Systems is simulated using a diagram as shown in Figure 10. 


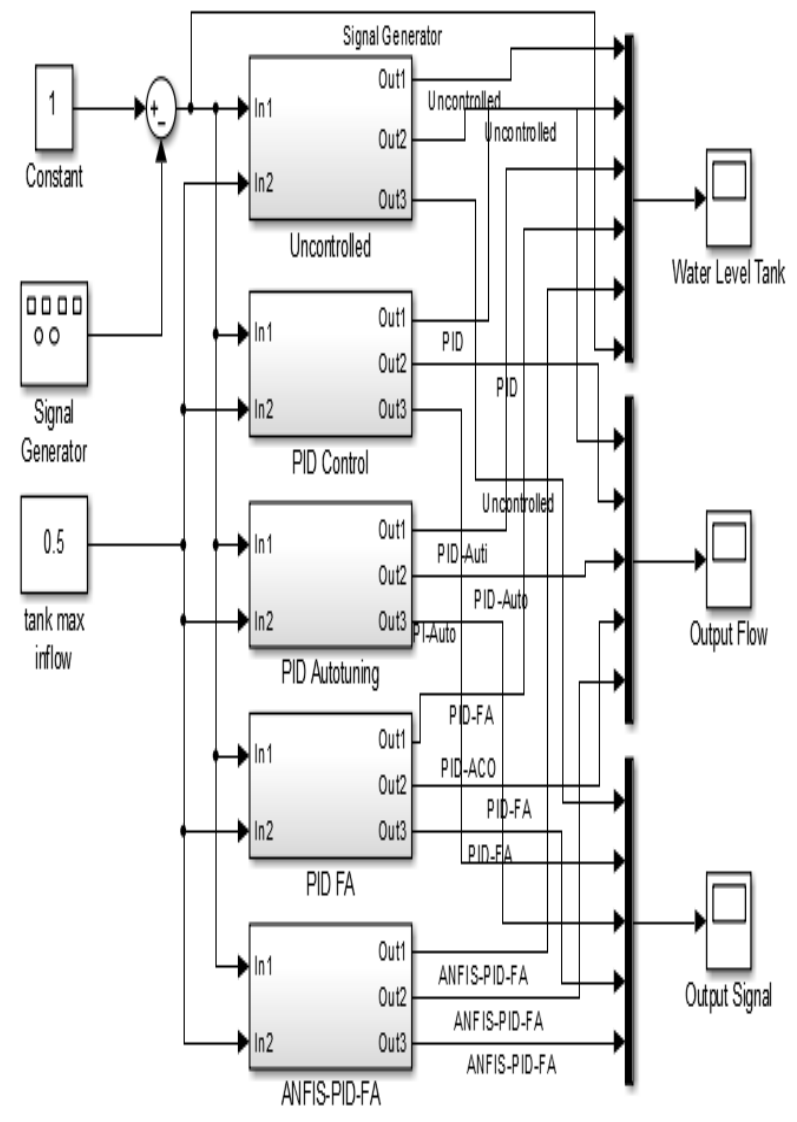

Figure. 10. Design of Water Level Control Systems

By considering Figure 10, all the integrated systems are run in a single flow for determining system performances based on the technical parameters. From the simulation results, the constant values of $\mathrm{Kp}, \mathrm{Ki}, \mathrm{Kd}$, Overshoot, and Undershoot can be seen in Table 2 .

Table 2. Overshot and Undershot

\begin{tabular}{lccccc}
\hline Unc & PID & $\begin{array}{c}\text { PID- } \\
\text { Auto }\end{array}$ & $\begin{array}{c}\text { PID- } \\
\text { FA }\end{array}$ & $\begin{array}{c}\text { ANFIS- } \\
\text { PID- } \\
\text { FA }\end{array}$ \\
\hline Kp & 0 & 1 & 0.2314 & 40.4904 & - \\
\hline Ki & 0 & 1 & 0.0089 & 0.0055 & - \\
\hline Kd & 0 & 0 & 1.3667 & 3.0319 & - \\
\hline $\begin{array}{l}\text { Overshot } \\
\text { Water } \\
\text { level }\end{array}$ & 0.3046 & 0.2751 & 0.0742 & 0.0033 & 0.0021 \\
\hline $\begin{array}{l}\text { Undershot } \\
\text { Water } \\
\text { level }\end{array}$ & 0.1853 & 0.1423 & 0.0572 & 0.0165 & 0.0093 \\
\hline $\begin{array}{l}\text { Overshot } \\
\text { Flow }\end{array}$ & 0.2952 & 0.2881 & 0.0284 & 0.0074 & 0.0072 \\
\hline $\begin{array}{l}\text { Undershot } \\
\text { Flow }\end{array}$ & 0.0250 & 0.0231 & 0.0087 & 0.0022 & 0.0096 \\
\hline
\end{tabular}

Water Level Tank simulation results can be also seen in Figure 10 as the characteristics during the system is controlled using various types of the controller. From these results, it is found that the Overshot Water Level I obtained in the un-controlling model of $0.3046 \mathrm{pu}$, PID model of $0.2751 \mathrm{pu}$, PID-Auto model of $0.0742 \mathrm{pu}$, PIDFA model of $0.0033 \mathrm{pu}$, and ANFIS-PID-FA of 0.0021 $\mathrm{pu}$ while the undershoot of the un-controlling model is $0.1853 \mathrm{pu}$, PID model is $0.1423 \mathrm{pu}$, PID-Auto model is
$0.0572 \mathrm{pu}$, PID-FA model is $0.0165 \mathrm{pu}$, and ANFISPID-FA model is $0.0093 \mathrm{pu}$. In addition, the output Flow simulation results are illustrated in Figure 11.

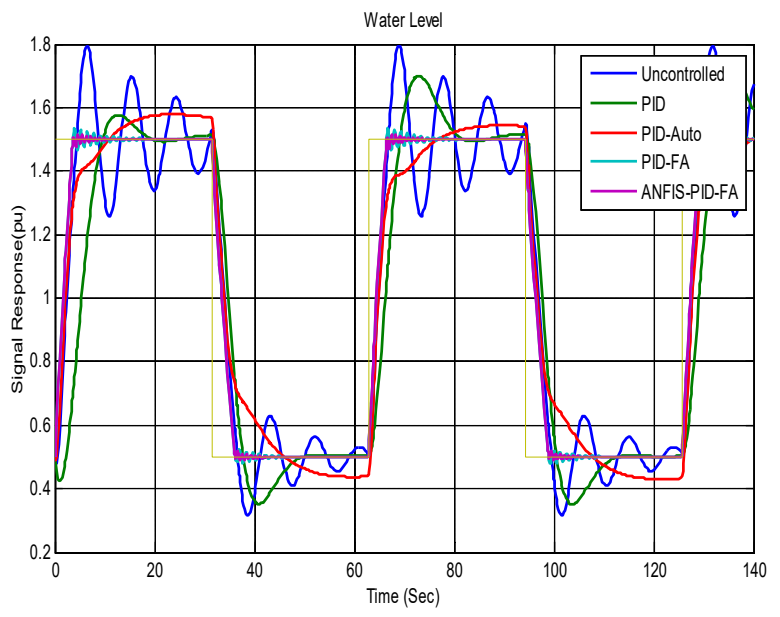

Figure. 11. Water Level Tank Results

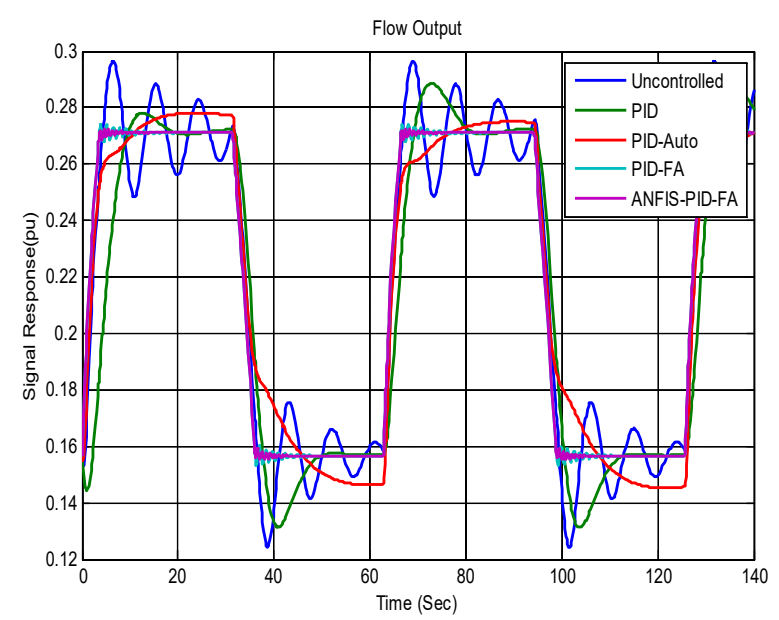

Figure. 12. Output Flow Results

As the previous performances, the results can be also known that the overshoot output flow on the uncontrolled model is remained in 0.2952 pu while PID model is reached $0.2881 \mathrm{pu}$. Moreover, other results are given in the PID-Auto model of $0.0284 \mathrm{pu}$, PID-FA model of $0.0074 \mathrm{pu}$, and ANFIS-PID-FA of $0.0072 \mathrm{pu}$. The undershot on the un-controlled model is $0.0250 \mathrm{pu}$, PID model is $0.0231 \mathrm{pu}$, PID-Auto model is $0.0087 \mathrm{pu}$, PID-FA model is $0.0022 \mathrm{pu}$, and ANFIS-PID-FA model is $0.0096 \mathrm{pu}$.

\section{CONCLUSION}

From the simulation results, it is known that the five control models show that the ANFIS-PID-FA model is the best control model. The ANFIS-PID-FA model has the smallest overshot and undershot on the water level and output flow. These works can be developed more with other methods as the appropriate design study in the further work.

\section{REFERENCES}

[1] X. Li, J. Li, and L. Shi, "Modeling and simulation of water level system," in Proceedings of the IEEE International Conference on Automation and Logistics, ICAL 2008, 2008, pp. 2856-2859.

[2] A. A. M. Eltaieb and Z. J. Min, "Automatic Water Level 
Control System," Int. J. Sci. Res., vol. 4, no. 12, pp. 15051509, 2015.

[3] B. Mondal, S. Rakshit, R. Sarkar, and N. Mandal, "Study of PID and FLC based water level control using ultrasonic level detector," in 2016 International Conference on Computer, Electrical and Communication Engineering, ICCECE 2016, 2017.

[4] Y.-T. Lin, Y.-C. Lin, and J.-Y. Han, "Automatic water-level detection using single-camera images with varied poses," Measurement, vol. 127, pp. 167-174, Oct. 2018.

[5] S. Omran, R. Broadwater, J. Hambrick, M. Dilek, C. Thomas, and F. Kreikebaum, "Load growth and power flow control with DSRs: Balanced vs unbalanced transmission networks," Electr. Power Syst. Res., vol. 145, pp. 207-213, Apr. 2017.

[6] E. Terzi, A. Cataldo, P. Lorusso, and R. Scattolini, "Modelling and predictive control of a recirculating cooling water system for an industrial plant," J. Process Control, vol. 68, pp. 205-217, Aug. 2018.

[7] C. M. Chew, M. K. Aroua, and M. A. Hussain, "Advanced process control for ultrafiltration membrane water treatment system," J. Clean. Prod., vol. 179, pp. 63-80, Apr. 2018.

[8] M. Ali, F. Hunaini, I. Robandi, and N. Sutantra, "Optimization of active steering control on vehicle with steer by wire system using Imperialist Competitive Algorithm (ICA)," in 2015 3rd International Conference on Information and Communication Technology (ICoICT), 2015, pp. 500-503.

[9] H. Nurohmah, M. Ali, and M. R. B. Djalal, "Desain Frekuensi Kontrol pada Hibrid Wind-Diesel Dengan PIDImperialist Competitive Algorithm (ICA)," J. Intake, vol. 6 no. 2, pp. 35-42, 2015

[10] N. Hamedazimi et al., "FireFly," in Proceedings of the 2014 ACM conference on SIGCOMM - SIGCOMM '14, 2014, pp. 319-330.

[11] M. Dorigo, M. Birattari, and T. Stutzle, "Ant colony optimization," IEEE Comput. Intell. Mag., vol. 1, no. 4, pp. $28-39,2006$

[12] A. N. Afandi et al., "Artificial salmon tracking algorithm: Preliminary designing approach for optimizing the integrated mixed energy composition," MATEC Web Conf., vol. 204, p. 4002, 2018.

[13] J. S. R. Jang, "ANFIS: Adaptive-Network-Based Fuzzy Inference System," IEEE Trans. Syst. Man Cybern., vol. 23, no. 3, pp. 665-685, 1993.

[14] M. F. Rachman, S. Muttaqin, and M. Ali, "Penggunaan Metode Imperialist Competitive Algorithm (ICA) untuk kontrol Frekuensi pada Wind-Turbine dan Hybrid WindDiesel,” in SAINTEK II-2017, UB, Malang, 2017, pp. 99102.

[15] M. Ali, "Kontrol Kecepatan Motor DC Menggunakan PID Kontroler Yang Ditunning Dengan Firefly Algorithm," $J$. Intake, vol. 3, no. 2, pp. 1-10, 2012.

[16] M. R. Djalal and M. Ali, "Particle Swarm Optimization Untuk Mengontrol Frekuensi Pada Hibrid Wind-Diesel," $J$. Intake, vol. 7, no. 2, pp. 1-13, 2016.

[17] D. H. Kusuma, M. Ali, and N. Sutantra, "The comparison of optimization for active steering control on vehicle using PID controller based on artificial intelligence techniques," in Proceedings - 2016 International Seminar on Application of Technology for Information and Communication, ISEMANTIC 2016, 2017.

[18] M. Ali, D. Ajiatmo, and M. Djalal, "Aplikasi ModifiedImperialist-Competitive-Algorithm (MICA) Untuk Merekonfigurasi Jaringan Radial," JEEE-U, vol. 1, no. 2, pp. 17-20, 2017.

[19] M. Ali, D. Ajiatmo, and M. R. Djalal, "Aplikasi ModifiedImperialist-Competitive-Algorithm (MICA) Untuk Merekonfigurasi Jaringan Radial Tenaga Listrik Pada Penyulang Mojoagung," J. JEEEU, vol. 1, no. 2, pp. 17-21, 2017. 
